\title{
Latitudinal variation in the microbiome of the sponge Ircinia campana correlates with host haplotype but not anti-predatory chemical defense
}

\author{
Clark M. Marino ${ }^{1,2}$, Joseph R. Pawlik¹, Susanna López-Legentil ${ }^{1}$, Patrick M. Erwin ${ }^{1, *}$ \\ ${ }^{1}$ Center for Marine Science and Department of Biology and Marine Biology, University of North Carolina Wilmington, \\ Wilmington, NC 28409, USA \\ ${ }^{2}$ Present address: Department of Ecology, Evolution, and Marine Biology, University of California Santa Barbara,
} Santa Barbara, CA 93106, USA

\begin{abstract}
Many marine sponges host diverse symbiotic microbial communities that have been implicated in the production of secondary metabolites. These metabolites may defend the host sponge from potential predators. Variability in symbiont communities across the range of the host sponge could alter levels of chemical defense. To investigate the relationship between symbiont composition and chemical defense, the microbiomes and palatability of tissue samples from Ircinia campana were characterized from 5 sites along a latitudinal gradient spanning temperate (South Atlantic Bight, SAB) and tropical (Caribbean) regions. Terminal restriction fragment length polymorphism analysis and Illumina sequencing of $16 \mathrm{~S}$ ribosomal RNA genes revealed that I. campana from different locations contained significantly distinct microbiomes and exhibited a consistent relationship of lower symbiont similarity over greater geographic distance (i.e. distance-decay). However, crude organic extracts of all samples of I. campana were unpalatable to assay fish Thalassoma bifasciatum in laboratory assays, indicating no difference in chemical defense across locations. Distinct haplotypes of I. campana were detected in populations from the $\mathrm{SAB}$ and Caribbean, correlating with the observed patterns of latitudinal variation in microbial symbiont communities. Our findings indicate that I. campana is chemically defended from fish predators across the range of the species and that latitudinal variation occurs in the microbiome of I. campana, driven by a combination of host-specific factors and region-specific environmental filtering of symbiont communities.
\end{abstract}

KEY WORDS: Symbiosis $\cdot$ Microbial community $\cdot$ Chemical defense $\cdot$ Biogeography $\cdot$ Porifera Intraspecific variation

\section{INTRODUCTION}

Many animals and plants host endosymbiotic microbial communities that are distinct from those found in the environment (Gaiero et al. 2013, McFall-Ngai et al. 2013). Although some of these microbes are parasitic, many endosymbionts form beneficial associations that increase host fitness through enhanced nutrient acquisition or decreased

${ }^{*}$ Corresponding author: erwinp@uncw.edu susceptibility to pathogens and predators (Moran 2007, Bennett \& Moran 2015). In some systems, the benefits that specific endosymbionts provide are well understood, but these hosts usually contain lowdiversity microbiomes (McFall-Ngai 2008, Smith \& Smith 2011, Shigenobu \& Wilson 2011, Davy et al. 2012). It has been more difficult to elucidate the benefits of individual microbial taxa that coexist in symbiotic communities with hundreds or thousands

(C) The authors 2017. Open Access under Creative Commons by Attribution Licence. Use, distribution and reproduction are unrestricted. Authors and original publication must be credited. 
of taxa (Hongoh 2011, Robles Alonso \& Guarner 2013). Examples of such complex symbiotic systems include the microbiomes of sponges, which can reach densities of $10^{8}$ to $10^{10}$ microorganisms per gram of sponge tissue and comprise up to $35 \%$ of sponge biomass (Hentschel et al. 2006). Recent work has begun to examine sponge microbiomes and the factors that influence their structure and variability (Taylor et al. 2007, Freeman \& Thacker 2011, Hentschel et al. 2012, Thacker \& Freeman 2012, Webster \& Taylor 2012).

Sponge-associated microbial communities are generally distinct from those in adjacent seawater and are largely host species-specific (Thomas et al. 2016), with symbiont communities varying significantly between sponge species but with individuals of the same species harboring similar microbiomes (Lee et al. 2011, Schmitt et al. 2012, Webster et al. 2013, Easson \& Thacker 2014, Reveillaud et al. 2014). This high degree of host specificity and symbiont stability is reported across broad longitudinal and bathymetric ranges (Erwin et al. 2012a, Olson \& Gao 2013, Pita et al. 2013b,c, Cárdenas et al. 2014, Reveillaud et al. 2014), temporal scales (Thiel et al. 2007, Erwin et al. 2012b, 2015, Simister et al. 2013, Hardoim \& Costa 2014) and in response to exposure to sub-lethal temperatures, elevated nutrient levels, and food shortages (Webster et al. 2008, 2011, Simister et al. 2012a,b, Pita et al. 2013a). Notable exceptions to these general trends in sponge microbiology also exist, where significant intraspecific variation in symbiont microbial communities has been detected across different habitats (Cleary et al. 2013, Weigel \& Erwin 2016) and latitudes (Taylor et al. 2005, Anderson et al. 2010), thus suggesting that host species is not the only factor that determines microbiome composition. Temperature and other ecosystem attributes vary strongly with latitude and may explain why differences in microbial communities were detected when sampling occurred across large latitudinal gradients and not across large longitudinal ranges.

Marine sponges have long been recognized as prolific producers of bioactive secondary metabolites, many with pharmaceutical applications (Erwin et al. 2010). More recently, the potential and realized contributions of symbiotic microorganisms to host defensive chemistry has suggested a link between the microbial ecology and chemical ecology of marine sponges. Investigations of secondary metabolite production in sponges have found evidence that symbiotic microbes are involved in the production of specific bioactive compounds originally attributed to host sponges, including chemical analyses of host and symbiont cell partitions and the characterization and localization of biosynthetic gene clusters (Bewley \& Faulkner 1998, Piel 2009, Hentschel et al. 2012, Flórez et al. 2015, Freeman et al. 2016). Other studies have targeted broader linkages between symbiont community composition and sponge chemistry, for example, documenting co-variation between microbial communities and metabolite profiles of the sponge Mycale hentscheli (Anderson et al. 2010). Given the importance of chemical defenses in structuring Caribbean sponge communities (Pawlik 2011, Loh \& Pawlik 2014), understanding the relationship between symbiont structure and host palatability has broad ecological importance. Further, spongeassociated microorganisms can contribute to the nutritional ecology of their hosts (Freeman et al. 2013), which may indirectly affect sponge chemical ecology by relaxing energy investment trade-offs between defensive metabolite production, growth and reproduction (Leong \& Pawlik 2010).

The objectives of this study were to determine intraspecific variation in the microbial community and chemical defense of Ircinia campana across a broad $(>2500 \mathrm{~km})$ geographic range spanning temperate and tropical latitudes. I. campana was chosen for this study because (1) it exhibits a large latitudinal range (extending from the tropical southern Caribbean to the temperate South Atlantic Bight, $\mathrm{SAB})_{i}(2)$ the chemical defenses of this species are well characterized (Pawlik et al. 1995, 2002); (3) the level of chemical defense is previously reported to vary across this range (Ruzicka \& Gleason 2009); and (4) members of the genus Ircinia are known to host abundant and diverse microbiomes (Erwin et al. 2012a, Pita et al. 2013b,c). Past work found that a mixture of furanosesterterpene tetronic acids protects I. campana from predation; however, it is unknown whether these chemicals are produced by the sponge or endosymbiotic microbes (Pawlik et al. 2002, Esteves et al. 2013). Tissue samples from specimens of $I$. campana from 5 locations in the Caribbean and SAB were collected and used to assess differences in chemical defense against fish predators using a standard laboratory palatability assay, and the microbial communities were assessed using terminal restriction fragment length polymorphism (T-RFLP) analyses and Illumina sequencing of partial 16S rRNA gene sequences. The taxonomic identity and haplotype diversity of sponge hosts were determined by sequencing a fragment of the mitochondrial gene cytochrome $c$ oxidase subunit I (COI). 


\section{MATERIALS AND METHODS}

\section{Sample collection and DNA extraction}

Sampling was conducted between May and September 2014 at 5 locations within the SAB (Wilmington, North Carolina and Gray's Reef, Georgia, USA) and Caribbean (Key Largo, Florida, USA; Carrie Bow Cay, Belize; Bocas del Toro, Panama) (Fig. 1). Tissue samples were non-fatally collected from individual Ircinia campana by cutting a notch in the lip of this vase-shaped sponge using a disposable scalpel. At each site, tissue samples from 10 sponges and 3 samples of ambient seawater $(500 \mathrm{ml})$ were collected using SCUBA at depths ranging from 10 to $20 \mathrm{~m}$. Owing to logistical constraints, no seawater was collected in Belize and only 2 seawater samples were collected in Panama. All sampled sponges were free

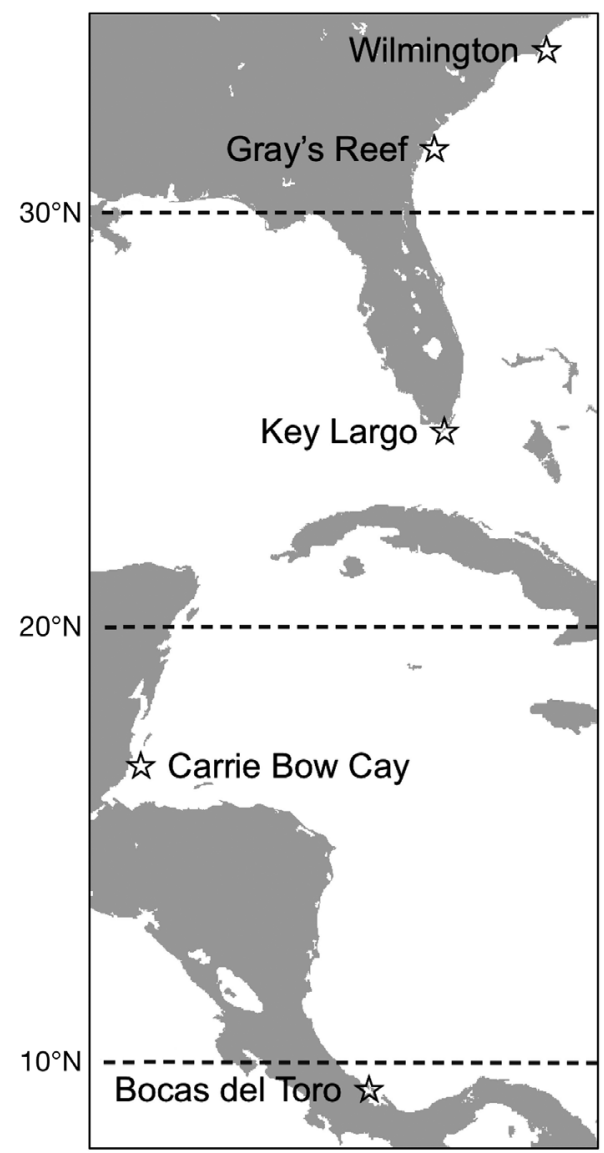

Fig. 1. Collection sites ( 5 ) within the South Atlantic Bight and the Caribbean: Wilmington, North Carolina (34 $7.926^{\prime} \mathrm{N}$, $\left.77^{\circ} 21.636^{\prime} \mathrm{W}\right)$; Gray's Reef, Georgia $\left(31^{\circ} 23.790^{\prime} \mathrm{N}\right.$, $80^{\circ}$ $\left.53.418^{\prime} \mathrm{W}\right)$; Key Largo, Florida $\left(24^{\circ} 56.657^{\prime} \mathrm{N}, 80^{\circ} 29.768^{\prime} \mathrm{W}\right)$; Carrie Bow Cay, Belize $\left(16^{\circ} 48.173^{\prime} \mathrm{N}, 88^{\circ} 4.928^{\prime} \mathrm{W}\right)$; and Bocas del Toro, Panama $\left(9^{\circ} 21.639^{\prime} \mathrm{N}, 82^{\circ} 16.680^{\prime} \mathrm{W}\right)$ of epibionts and visible signs of disease. For molecular analyses, a $1 \mathrm{ml}$ piece of tissue containing external pinacoderm and mesohyl was collected from each sponge sample, preserved in $100 \%$ ethanol and stored at $-20^{\circ} \mathrm{C}$. For chemical analyses, the remaining sponge tissue was frozen wet and stored at $-20^{\circ} \mathrm{C}$. Seawater samples were concentrated on $0.2 \mu \mathrm{m}$ filters, preserved in $100 \%$ ethanol and stored at $-20^{\circ} \mathrm{C}$. Each ethanol-preserved tissue sample and concentrated seawater sample was separately extracted using the DNeasy Blood \& Tissue Kit (Qiagen). Full strength and 1:10 diluted DNA extracts were used as templates in subsequent PCR amplifications.

\section{Molecular identification of host sponges}

From each location, 3 sponge samples were haphazardly selected for molecular identification (Belize: C3, C6, C7; Panama: P1, P3, P6; Florida: L2, L4, L5; Georgia: G1, G7, G8; North Carolina: W4, W8, W9). A degenerated version of the universal barcoding forward primer dgLCO1490 (Meyer et al. 2005) (5'GGT CAA CAA ATC ATA AAG AYA TYG G-3') and the reverse primer COX1-R1 (Rot et al. 2006) (5'-TGT TGR GGG AAA AAR GTT AAA TT-3') were used for PCR amplification of a fragment (ca. $1000 \mathrm{bp}$ ) of the COI gene, corresponding to the standard barcoding ('Folmer') partition (Folmer et al. 1994, Hebert et al. 2003) and the I3-M11 partition (Erpenbeck et al. 2006). Amplification was performed with $1 \mu \mathrm{l}$ of each primer $(10 \mu \mathrm{M}), 12 \mu \mathrm{l}$ (0.5 units) of MyTaq ${ }^{\mathrm{TM}}$ HS Red Mix DNA polymerase (Bioline), 1 to $2 \mu$ of DNA template, and PCR water to a total reaction volume of $25 \mu \mathrm{l}$. Thermocycler conditions were an initial denaturating step at $94^{\circ} \mathrm{C}$ for $5 \mathrm{~min}$, followed by 32 cycles of $94^{\circ} \mathrm{C}$ for $30 \mathrm{~s}, 42^{\circ} \mathrm{C}$ for $30 \mathrm{~s}$ and $72^{\circ} \mathrm{C}$ for $1.5 \mathrm{~min}$, and a final extension at $72^{\circ} \mathrm{C}$ for $5 \mathrm{~min}$. PCR products were purified using the QIAquick PCR Purification Kit (QIAGEN) and used as templates for sequencing reactions with BigDye terminator v3.1 and the same primer set used during initial amplification step, then analyzed on a 3130xl Genetic Analyzer (Applied Biosystems) at the University of North Carolina Wilmington Center for Marine Science. Consensus sequences were constructed from forward and reverse sequence reads aligned using Geneious v8 (Kearse et al. 2012) and final sequences were deposited in GenBank (accession numbers KR819143 to KR819157). A final alignment including sequences from the congeners I. fasciculata, I. oros and I. variabilis from Spain (Erwin et al. 2012a) and for I. strobilina and $I$. 
felix from the Bahamas (Pita et al. 2013b) was built using ClustalW (Larkin et al. 2007) with a gap opening penalty of 24 and a gap extension penalty of 4 (Erwin \& Thacker 2008). According to the Bayesian information criterion, the best model of nucleotide substitution for maximum likelihood analysis was the Hasegawa-Kishino-Yano (HKY) model (Hasegawa et al. 1985). A maximum likelihood tree was built using the HKY model, the nearest-neighbor-interchange heuristic method, and 1000 bootstrap replicates (Felsenstein 1985) with Mega v6.06 (Tamura et al. 2013).

\section{Characterization of microbial symbionts by T-RFLP analysis}

The universal bacterial forward primer Eco8F (Turner et al. 1999) (5'-AGA GTT TGA TCC TGG CTC AG-3'), tagged with 6-carboxyfluorescein, and the reverse primer 1509R (Martínez-Murcia et al. 1995) (5'-GGT TAC CTT GTT ACG ACT T-3'), were used to amplify a ca. $1500 \mathrm{bp}$ fragment of the $16 \mathrm{~S}$ rRNA gene from sponge ( 7 to 10 samples per location) and seawater (2 to 3 samples per location) extracts, using the same reaction mixture detailed above for sponge COI genes. Thermocycler conditions were an initial denaturating step at $94^{\circ} \mathrm{C}$ for $2 \mathrm{~min}$, followed by 35 cycles of $94^{\circ} \mathrm{C}$ for $15 \mathrm{~s}, 50^{\circ} \mathrm{C}$ for $15 \mathrm{~s}, 72^{\circ} \mathrm{C}$ for $20 \mathrm{~s}$, and a final extension at $72^{\circ} \mathrm{C}$ for $5 \mathrm{~min}$. PCR reactions for each sponge and seawater sample were run in triplicate and the products were combined and gel-purified using the QIAquick Gel Extraction Kit (QIAGEN). DNA concentrations were quantified on a NanoDrop 1000 Spectrophotometer (Thermo Scientific) and $100 \mathrm{ng}$ of purified PCR product was digested separately with the restriction enzymes HaeIII and MspI (FastDigest, Thermo Scientific) and ethanolprecipitated to remove excess salts. Samples were eluted in $10 \mu$ l formamide and $0.5 \mu$ l GeneScan 500 ROX size standard (Life Technologies), heated at $96^{\circ} \mathrm{C}$ for $1 \mathrm{~min}$, immediately cooled on ice for $2 \mathrm{~min}$, and analyzed by capillary electrophoresis on a 3130xl Genetic Analyzer (Applied Biosystems).

The lengths of terminal restriction fragments (T-RFs) were determined by comparison with internal size standards using the program PeakScanner (Applied Biosystems). T-RFs below 50 relative units of fluorescence (background noise), smaller than $50 \mathrm{bp}$ or larger than $500 \mathrm{bp}$ (beyond size standard resolution) were excluded. Additional filtering and alignment of the T-RFLP peak profiles was carried out in the program T-REX (Culman et al. 2009) and relative abundance matrices were calculated. Data were de-noised by applying a cutoff value of 1.5 SD (Abdo et al. 2006). T-RFs were aligned using a clustering threshold of $1 \mathrm{bp}$ then standardized by relative peak area.

Statistical analyses of T-RFLP profiles were performed in PRIMER v6 (Clarke 1993, Clarke \& Gorley 2006) and PERMANOVA+ (Plymouth Marine Laboratory). Square root transformations were applied to relative abundance matrices and a Bray-Curtis similarity matrix was constructed for each restriction enzyme dataset. Non-metric multidimensional scaling (NMDS) plots were generated to visualize bacterial community similarity. Permutational multivariate analyses of variance (PERMANOVAs) (Anderson 2001, McArdle \& Anderson 2001) were used to test for variability between sources (seawater and sponges) and among locations (sponges only), with significance determined by permutational $\mathrm{p}$-values or Monte-Carlo asymptotic p-values in comparisons with few permutations. Pairwise comparisons of dispersion (PERMDISPs) were performed to determine the effect of heterogeneity for significant PERMANOVA outcomes. Critical values for significance for all pairwise comparisons were corrected using the Benjamini-Yekutieli (B-Y) false discovery rate (Benjamini \& Yekutieli 2001).

\section{Characterization of microbial symbionts by Illumina sequencing}

DNA extracts from sponge (3 to 4 replicates per location) and seawater ( 2 to 3 replicates per location) samples were sent to Molecular Research LP (Shallowater, Texas) for amplification, library construction and multiplexed, paired-end sequencing of partial (V4 region) 16S rRNA gene sequences using the bacterial and archaeal specific primers 515F (5'-GTG CCA GCM GCC GCG GTA A-3') and 806R (5'-GGA CTA CVS GGG TAT CTA AT-3') (Bates et al. 2011). Raw sequences were deposited into the sequence read archive of GenBank (accession number SRP058983).

Raw sequences were processed using mothur v1.33.3 (Schloss et al. 2009). Low-quality sequences were removed using the following parameters: no ambiguous bp, no bp differences from barcode, differences from primer $\leq 2$, a maximum of 8 homopolymers, a minimum length of $200 \mathrm{bp}$, and a maximum length of $300 \mathrm{bp}$. Unique sequences were then aligned to a trimmed (V4 region) SILVA v119.4 database (Yilmaz et al. 2014). Poorly aligned sequences were removed and the remaining sequences were trimmed to an overlapping alignment space. Sequences were pre-clustered (differences $=2$; Huse et al. 
2010) and chimeras were identified and removed using UCHIME (Edgar et al. 2011), as implemented in mothur. Sequences were taxonomically classified using the Greengenes v13.5.99 database (DeSantis et al. 2006) and non-target sequences were removed. Sequences were clustered into operational taxonomic units (OTUs) according to $97 \%$ sequence identity (average neighbor algorithm). A shared table was created with the abundance of each OTU in each sponge or seawater sample. The data were subsampled to the lowest read count $(n=9226)$ to standardize sequencing depth across samples.

Univariate and multivariate statistical analyses were conducted to compare the diversity and similarity of microbial communities. Univariate metrics included observed OTU richness (number of 97\% OTUs), expected OTU richness (Chao1 and abundance-based coverage estimator [ACE] indices; Chao 1984, Chao \& Lee 1992), and OTU diversity calculations (Simpson's inverse index and Shannon index; Shannon 1948, Simpson 1949). Multivariate statistical analyses were performed in PRIMER v6 and PERMANOVA+, as described above. In addition, similarity percentage (SIMPER) analyses were conducted to identify the individual OTUs driving community-level differentiation between groups.

\section{Testing for isolation-by-distance effects}

To determine whether differences in symbiont community similarity were correlated with geographic distances among host sponge populations, Mantel tests were conducted in R v3.1.2 (R Core Team 2014) using the package ade4 (Dray \& Dufour 2007). Three separate Mantel tests were run using Bray-Curtis similarity values derived from T-RFLP profiles (HaeIII and MspI datasets) and Illumina sequence data to test for isolation-by-distance effects (i.e. distancedecay relationships).

\section{Metabolite extraction and laboratory feeding assays}

Extraction of secondary metabolites from sponge tissue and subsequent laboratory feeding assays were performed following Marty \& Pawlik (2015). Briefly, metabolites were extracted from wet sponge tissue using a 1:1 solvent mixture of dichloromethane and methanol followed by a second tissue extraction with methanol alone, and the solvents were evaporated to provide the crude organic extract. The crude extract was mixed at the same volumetric concentration as it occurred in the sponge tissue with a squid mantle-based food paste containing alginic acid and food coloring to standardize paste color. The paste was extruded from a syringe into a calcium chloride solution, which hardened the paste into a noodle-like strand from which extract-treated pellets could be cut with a scalpel. Control pellets were made in the same way, but without the addition of crude extract.

Feeding deterrence was determined using a wellestablished laboratory feeding assay with the generalist predatory bluehead wrasse Thalassoma bifasciatum (Marty \& Pawlik 2015), which produces results consistent with field assays of sponge palatabilty against a natural suite of reef fishes (Chanas et al. 1997), including sponges in the genus Ircinia (Pawlik et al. 2002). Control and treated pellets were presented to 10 groups of 3 yellow-phase bluehead wrasses $T$. bifasciatum, with each group held in a separate aquarium cell. Feeding results were evaluated using a modified version of Fisher's exact test, with sponge tissue samples considered deterrent if 6 or fewer pellets were eaten ( $\mathrm{p} \leq 0.057$; Marty \& Pawlik 2015).

\section{RESULTS}

\section{Host sponge haplotypes}

Partial COI gene sequences (973 bp) were recovered from tissue samples of 15 individuals of Ircinia campana and revealed 2 haplotypes of I. campana distinguished by a single mutation (pyrimidine transition) in the I3-M11 region. The haplotypes exhibited a biogeographic distribution, with I. campana from SAB locations (North Carolina, Georgia) exclusively showing Haplotype 1 and those from Caribbean locations (Belize, Panama) exclusively showing Haplotype 2. Both haplotypes were detected in Florida (1 sample presented Haplotype 1, 2 samples presented Haplotype 2). Phylogenetic analysis grouped all samples of I. campana together in a modestly supported monophyletic clade (65\% bootstrap support) separated from Mediterranean and Bahamian species of Ircinia (Fig. S1 in Supplement 1 at www.intres.com/articles/suppl/m565p053_supp1.pdf).

\section{T-RFLP analysis}

The HaeIII digest recovered 114 unique T-RFs across all samples: seawater yielded 76, while $I$. 


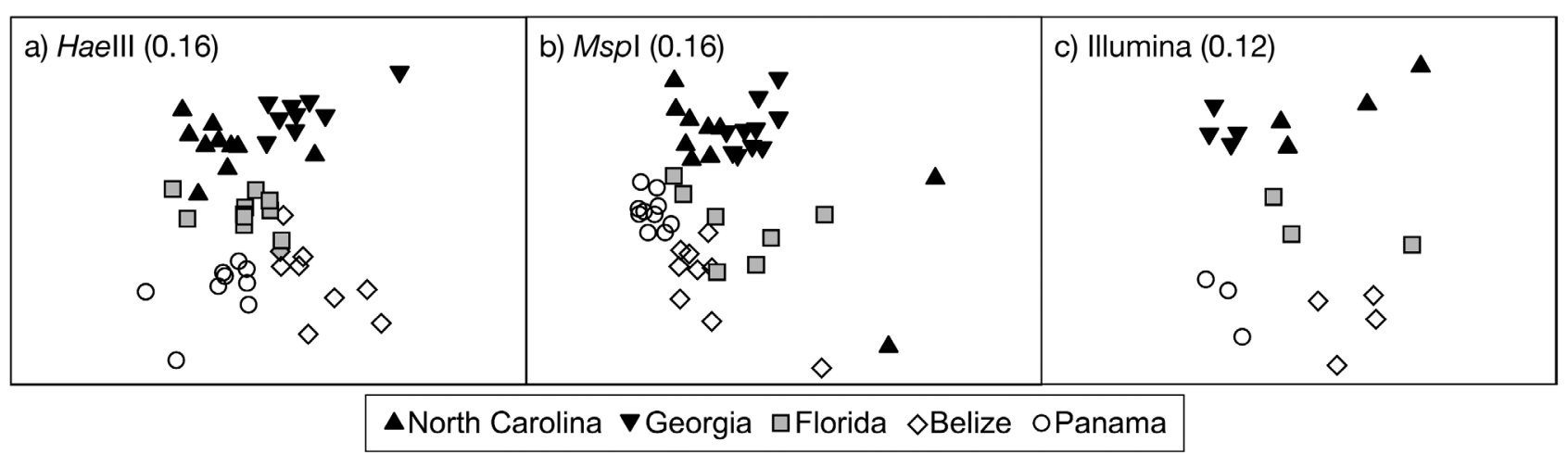

Fig. 2. NMDS plots of microbial community structure in Ircinia campana from different collection sites based on Bray-Curtis similarity of (a) T-RFLP profiles using HaeIII, (b) T-RFLP profiles using MspI and (c) OTU profiles using Illumina sequences. Stress values are shown in parentheses

campana from North Carolina, Georgia, Florida, Belize, and Panama yielded 73, 66, 71, 61, and 65, respectively. The MspI digest yielded 116 unique TRFs: seawater yielded 72, while I. campana from North Carolina, Georgia, Florida, Belize, and Panama yielded 59, 57, 70, 50, and 74, respectively. In NMDS plots for both digests, seawater and sponge-associated bacterial communities were clearly differentiated (Fig. S2 in Supplement 1) with sponge-associated bacterial communities generally clustered by location (Fig. 2). PERMANOVA results revealed significant effects of source (HaeIII: $F=$ 10.038, p < 0.001; MspI: $F=6.7879, \mathrm{p}<0.002)$ and location nested within source (HaeIII: $F=7.3365$, p $<0.001$; MspI: $F=73.133, \mathrm{p}<0.001)$ based on microbial community structure. Further, all pairwise comparisons across locations for sponge-associated microbial communities were significant $(p<0.002$; Table 1). PERMDISP results reported significant differences in the homogeneity of dispersion between seawater and sponge-associated microbial communities from different locations, except between $I$. campana from North Carolina and seawater in the MspI digest. No significant PERMDISP results were consistently found (i.e. in both enzyme datasets) among sponge-associated microbial communities from different locations, although pairwise comparisons between Georgia and Florida and between Florida and Panama were significant for 1 enzyme dataset (MspI; Table 1).

Table 1. Permutational statistical analysis of T-RFLP data (HaeIII and MspI digests) for microbial community structure (PERMANOVA) and homogeneity of dispersion (PERMDISP) among sponge tissue samples and seawater samples. Main tests of source (sponge tissue, seawater) and location (collection site) are shown, along with pairwise comparisons among samples of Ircinia campana from different locations and seawater samples. Bold: significant comparisons following B-Y correction with asterisks denoting significance level $\left({ }^{*} \alpha=0.05,{ }^{* *} \alpha=0.01\right)$

\begin{tabular}{|c|c|c|c|c|c|c|c|c|}
\hline \multirow[t]{2}{*}{ Pairwise comparison } & \multicolumn{2}{|c|}{ PERMANOVA (HaeIII) } & \multicolumn{2}{|c|}{ PERMANOVA (MspI) } & \multicolumn{2}{|c|}{ PERMDISP (HaeIII) } & \multicolumn{2}{|c|}{ PERMDISP (MspI) } \\
\hline & $t$ & p-value & $t$ & p-value & $t$ & p-value & $t$ & p-value \\
\hline Belize-Georgia & 3.8933 & $0.001^{* *}$ & 4.4639 & $0.001^{* *}$ & 0.3912 & 0.757 & 1.8491 & 0.091 \\
\hline Belize-Florida & 2.8041 & $0.001^{* *}$ & 2.212 & $0.001^{* *}$ & 0.9498 & 0.365 & 0.9218 & 0.494 \\
\hline Belize-Panama & 2.6786 & $0.001^{* *}$ & 3.322 & $0.001^{* *}$ & 0.3562 & 0.776 & 2.1272 & 0.032 \\
\hline Belize-North Carolina & 3.6819 & $0.001^{* *}$ & 2.9231 & $0.001^{* *}$ & 0.3936 & 0.718 & 0.8811 & 0.508 \\
\hline Georgia-Florida & 3.4956 & $0.001^{* *}$ & 3.4093 & $0.002^{* *}$ & 0.3919 & 0.779 & 3.9254 & $0.005^{*}$ \\
\hline Georgia-Panama & 4.1855 & $0.001^{* *}$ & 5.2375 & $0.001^{* *}$ & 0.0148 & 0.99 & 0.2897 & 0.816 \\
\hline Georgia-North Carolina & 2.5523 & $0.001^{* *}$ & 2.5504 & $0.001^{* *}$ & 0.8014 & 0.534 & 2.0779 & 0.069 \\
\hline Florida-Panama & 3.0235 & $0.001^{* *}$ & 2.8882 & $0.001^{* *}$ & 0.3868 & 0.761 & 4.8230 & $0.001^{* *}$ \\
\hline Florida-North Carolina & 2.5612 & $0.001^{* *}$ & 2.0928 & $0.001^{* *}$ & 1.6213 & 0.129 & 0.2929 & 0.784 \\
\hline Panama-North Carolina & 3.4297 & $0.001^{* *}$ & 3.1791 & $0.001^{* *}$ & 0.7381 & 0.539 & 2.2020 & 0.023 \\
\hline Belize-Seawater & 5.3204 & $0.001^{* *}$ & 4.4762 & $0.001^{* *}$ & 6.7057 & $0.001^{* *}$ & 4.9844 & $0.001^{* *}$ \\
\hline Georgia-Seawater & 5.2698 & $0.001^{* *}$ & 5.6203 & $0.001^{* *}$ & 6.5974 & $0.001^{* *}$ & 8.6570 & $0.001^{* *}$ \\
\hline Florida-Seawater & 5.3776 & $0.001^{* *}$ & 3.7855 & $0.001^{* *}$ & 8.6670 & $0.001^{* *}$ & 4.5162 & $0.003^{* *}$ \\
\hline Panama-Seawater & 5.4425 & $0.001^{* *}$ & 4.8767 & $0.001^{* *}$ & 6.3081 & $0.001^{* *}$ & 9.4360 & $0.001^{* *}$ \\
\hline North Carolina-Seawater & 5.0850 & $0.001^{* *}$ & 4.3398 & $0.001^{* *}$ & 7.2846 & $0.001^{* *}$ & 2.4188 & 0.048 \\
\hline
\end{tabular}


Table 2. Richness and diversity of microbial communities in tissue samples of Ircinia campana and samples of ambient seawater (mean $\pm \mathrm{SE}$ ). Comparisons among all sponge tissue and seawater samples (all) and among samples of $I$. campana from different locations are shown. ${ }^{*}$ Significant $(p<0.05)$ differences between sponge and seawater communities; no significant differences were detected among populations of $I$. campana. $S_{\text {obs }}=$ average observed OTU richness; $S_{\mathrm{Chao1}}=$ Chao1 expected OTU richness; $S_{\mathrm{ACE}}=\mathrm{ACE}$ expected OTU richness; $H=$ Shannon diversity index; $1 / D=$ inverse Simpson index

\begin{tabular}{|lccccc|}
\hline Source & $S_{\mathrm{obs}}$ & $S_{\mathrm{Chao} 1}$ & $S_{\mathrm{ACE}}$ & $H$ & $1 / D$ \\
\hline Seawater (all) & $710 \pm 26^{*}$ & $2441 \pm 127$ & $4583 \pm 239$ & $4.15 \pm 0.05^{*}$ & $21.5 \pm 1.2^{*}$ \\
I. campana (all) & $615 \pm 8^{*}$ & $2326 \pm 73$ & $4155 \pm 139$ & $4.53 \pm 0.02^{*}$ & $44.9 \pm 1.5^{*}$ \\
I. campana & & & & & \\
-North Carolina & $604 \pm 21$ & $2197 \pm 177$ & $4131 \pm 397$ & $4.46 \pm 0.06$ & $43.5 \pm 3.5$ \\
- Georgia & $598 \pm 14$ & $2367 \pm 174$ & $4203 \pm 353$ & $4.52 \pm 0.04$ & $42.6 \pm 1.8$ \\
-Florida & $608 \pm 5$ & $2194 \pm 142$ & $4352 \pm 402$ & $4.55 \pm 0.03$ & $47.6 \pm 2.7$ \\
-Belize & $634 \pm 20$ & $2399 \pm 170$ & $4228 \pm 294$ & $4.50 \pm 0.06$ & $42.8 \pm 4.7$ \\
-Panama & $633 \pm 19$ & $2481 \pm 178$ & $3830 \pm 104$ & $4.65 \pm 0.03$ & $49.6 \pm 3.6$ \\
\hline
\end{tabular}

\section{Illumina sequence analysis}

A total of 9055 microbial OTUs were recovered, with samples of $I$. campana containing 5480 OTUs from 33 bacterial and archaeal phyla, and seawater samples containing 4363 OTUs from 34 bacterial and archaeal phyla. The seawater microbial community was dominated by Proteobacteria (68.2\%), which in turn was dominated by Alphaproteobacteria and Gammaproteobacteria (33.6\% and $31 \%$ of the total reads, respectively). Other abundant phyla included Chloroflexi (6\%), Bacteroidetes (4.2\%), Acidobacteria $(3 \%)$, the bacterial group PAUC34f $(3 \%)$, Euryarchaeota $(2.5 \%)$, Cyanobacteria $(2.4 \%)$, Gemmatimonadetes $(1.9 \%)$, Nitrospirae $(1.4 \%)$, Verrucomicrobia $(1.4 \%)$, the bacterial group SAR406 $(1.4 \%)$, and Poribacteria $(1.1 \%)$. Each of the remaining 22 phyla contributed $<1 \%$ of the total reads for the seawater microbial community. Microbial communities in I. campana were dominated by Proteobacteria $(51.5 \%)$, namely the classes Gammaproteobacteria and Alphaproteobacteria $(27.4 \%$ and $17.6 \%$ of the total reads, respectively). Other abundant taxa included Chloroflexi (13.9\%), Actinobacteria (9.3\%), Bacteroidetes (5.7\%), Cyanobacteria (4.6\%), the bacterial group SBR1093 (3.5\%), Thaumarcheota (3\%), Acidobacteria $(2.4 \%)$, and the microbial group SAR406 (1.5\%). Each of the remaining 26 phyla contributed $<1 \%$ of the total reads. See Table S1 in Supplement 2 at www.int-res.com/articles/suppl/m565 p053_supp2.xlsx for the microbial community composition of each sample.

The microbial communities in I. campana exhibited lower richness and greater diversity compared to am- bient seawater communities, with $I$. campana from different locations showing similar levels of OTU diversity (Table 2). Observed OTU richness was significantly greater $(\mathrm{p}<$ 0.001) in seawater compared to $I$. campana, while expected OTU richness (ACE, Chao1) was not significantly different $(p>0.11)$ between seawater and sponge-associated communities. Both diversity indices (Shannon and inverse Simpson) were significantly higher $(\mathrm{p}<0.001)$ in $I$. campana compared to seawater communities. Comparisons of microbial community richness and diversity among the different populations of $I$. campana revealed no significant differences $(p>0.15)$, indicating similar levels of symbiont diversity across the investigated biogeographic range of I. campana.

A comparison of OTU profiles revealed that few microbial OTUs $(8.7 \%, \mathrm{n}=788)$ were shared between I. campana and seawater samples (Fig. S3 in Supplement 1). Notably, the number of shared OTUs was extremely low $(0.01 \%, \mathrm{n}=11)$ when rare OTUs were excluded $(<0.1 \%$ of total reads), indicating that most shared OTUs have low abundances in one or both sources (Fig. S3 in Supplement 1). A similar comparison among samples of I. campana from different locations revealed that, although rare OTUs may be location-specific, many abundant microbes were found in I. campana from all collection sites (Fig. 3). A total of 291 symbiont OTUs were present in at least 1 sponge sample from all sites ( $\mathrm{n}=69$ with rare OTUs excluded; Fig. 3) and 119 OTUs were present in all samples of I. campana from all sites (i.e. 'core' OTUs; Table S1 in Supplement 2), with these core OTUs accounting for the majority of symbiont sequences (79.2 to $87.0 \%$ ). Accordingly, NMDS plots revealed clear differences between seawater and sponge-associated microbial communities (Fig. S4 in Supplement 1), and spongeassociated microbial communities generally clustered by location (Fig. 2). PERMANOVA results revealed significant effects of source $(F=18.835$, p < $0.002)$ and location nested within source $(F=4.256$, $\mathrm{p}<0.001$ ) on microbial community structure. Pairwise comparisons revealed that microbial communities of I. campana from Georgia were significantly different from all other sponge samples except for those from North Carolina, while the microbial communities of I. campana from North Carolina were 

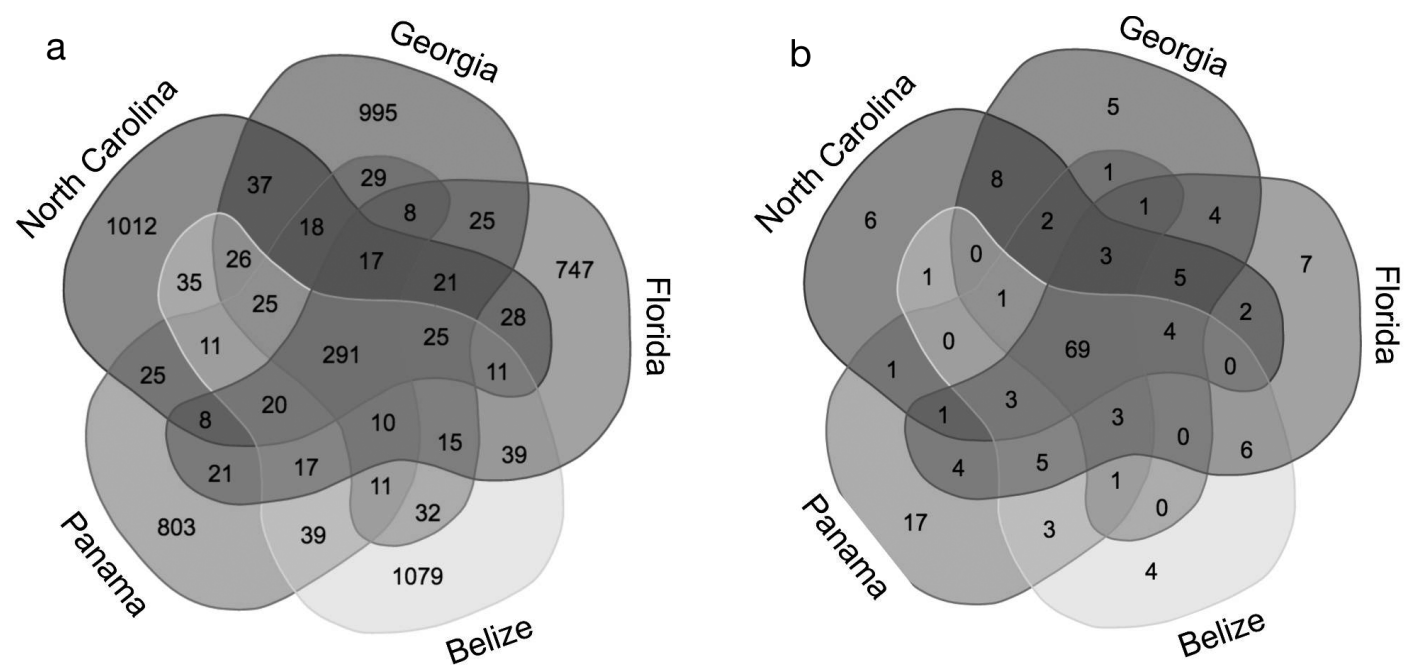

Fig. 3. Venn diagrams comparing the overlap in microbial OTU profiles of Ircinia campana from different locations for (a) all symbiont OTUs and (b) abundant symbiont OTUs ( $\geq 0.1 \%$ of total reads)

significantly different from sponge samples collected in Panama and Belize, but not from samples collected in Florida (Table 3). The microbial communities of $I$. campana from Florida, Belize and Panama were not significantly different from each other (Table 3). PERMDISP results found significant differences in the homogeneity of dispersion between seawater and sponge-associated microbial

Table 3. Permutational statistical analysis of Illumina data for microbial community structure (PERMANOVA) and homogeneity of dispersion (PERMDISP) among sponge tissue samples and seawater samples. Main tests of source (sponge tissue, seawater) and location (collection site) are shown, along with pairwise comparisons among samples of I. campana from different locations and seawater samples. Bold: significant comparisons following B-Y correction with asterisks denoting significance level $\left({ }^{*} \alpha=0.05,{ }^{* *} \alpha=0.01\right)$; ${ }^{\mathrm{m}}$ MonteCarlo asymptotic p-value

\begin{tabular}{|lclll|}
\hline \multirow{2}{*}{ Pairwise comparison } & \multicolumn{2}{c}{ PERMANOVA } & \multicolumn{2}{c|}{ PERMDISP } \\
& $t$ & p-value & $t$ & p-value \\
\hline Belize-Georgia & 2.8651 & $\mathbf{0 . 0 0 3}^{* * m}$ & 5.5179 & 0.024 \\
Belize-Florida & 1.4408 & $0.097^{\mathrm{m}}$ & 0.1241 & 0.836 \\
Belize-Panama & 1.8743 & $0.035^{\mathrm{m}}$ & 3.1695 & 0.118 \\
Belize-North Carolina & 2.0237 & $\mathbf{0 . 0 0 9}^{* \mathrm{~m}}$ & 0.5603 & 0.554 \\
Georgia-Florida & 2.2043 & $\mathbf{0 . 0 1 5}^{* \mathrm{~m}}$ & 7.1253 & 0.019 \\
Georgia-Panama & 3.0662 & $\mathbf{0 . 0 0 2}^{* * \mathrm{~m}}$ & 2.1198 & 0.094 \\
Georgia-North Carolina & 1.9746 & $0.018^{\mathrm{m}}$ & 6.8759 & 0.031 \\
Florida-Panama & 1.6217 & $0.083^{\mathrm{m}}$ & 3.9587 & 0.116 \\
Florida-North Carolina & 1.5052 & $0.092^{\mathrm{m}}$ & 0.7740 & 0.438 \\
Panama-North Carolina & 2.2381 & $0.008^{* \mathrm{~m}}$ & 4.1331 & 0.029 \\
Belize-Seawater & 4.4062 & $\mathbf{0 . 0 0 3}^{* *}$ & 3.5103 & $\mathbf{0 . 0 0 5}^{*}$ \\
Georgia-Seawater & 4.6915 & $\mathbf{0 . 0 0 3}^{* *}$ & 5.6654 & $\mathbf{0 . 0 0 4}^{*}$ \\
Florida-Seawater & 3.8975 & $\mathbf{0 . 0 0 1}^{* * \mathrm{~m}}$ & 3.1115 & $\mathbf{0 . 0 1 5}^{*}$ \\
Panama-Seawater & 3.9866 & $\mathbf{0 . 0 0 1}^{* *}$ & 4.3046 & $\mathbf{0 . 0 0 4}^{*}$ \\
North Carolina-Seawater & 4.4309 & $\mathbf{0 . 0 0 1}^{* *}$ & 3.2796 & $\mathbf{0 . 0 0 4}^{*}$ \\
\hline
\end{tabular}

communities, but not among sponge-associated microbial communities from different locations (Table 3).

SIMPER analyses revealed that differences among microbial communities of I. campana samples from different locations were driven by variations in the abundance of multiple symbiont OTUs rather than a single OTU (Table S2 in Supplement 2). A single OTU never contributed more than $6.3 \%$ to the total dissimilarity and most contributed less than $3 \%$. Although many of these OTUs maintained relative abundances $>1 \%$ regardless of collection location, some symbionts were abundant in sponges from one location while existing at very low concentrations in sponges from other sites (Table S2 in Supplement 2). For example, the actinobacterium OTU000015 (family Acidimicrobiales) was rare in sponges from Panama $(0.16 \%$ relative abundance) while common at the remaining sites (1.10 to $4.19 \%$ ), and the deltaproteobacterium OTU000053 (family Syntrophobacterales) was common in sponges from Belize $(2.77 \%)$ while rare in sponges from the remaining locations $(0.05$ to $0.43 \%$; Table S2 in Supplement 2).

\section{Isolation-by-distance effects}

Mantel tests revealed significant correlations between geographic distance and the similarity of sponge-associated microbial communities for all datasets (T-RFLP HaeIII: $\mathrm{r}=0.63, \mathrm{p}<$ 0.001; T-RFLP MspI: $\mathrm{r}=0.54, \mathrm{p}<0.001$; Illu- 
mina: $\mathrm{r}=0.68, \mathrm{p}<0.001$ ), indicating a strong distance-decay relationship within the microbiome of $I$. campana.

\section{Laboratory feeding assays}

Laboratory feeding assays using the bluehead wrasse Thalassoma bifasciatum did not reveal palatability differences between organic extracts of tissue samples of I. campana from different locations, and all samples were unpalatable to $T$. bifasciatum (Fig. 4). Mean palatability across locations ranged from 0 to 2 pellets of 10 eaten, well below the threshold considered palatable for this assay (Marty \& Pawlik 2015).

\section{DISCUSSION}

In this study, variation in the microbial symbiont community and anti-predatory chemical defense of the sponge Ircinia campana was investigated along a latitudinal gradient spanning $2500 \mathrm{~km}$ from temperate to tropical habitats. Multiple symbiont profiling methods revealed that I. campana from different geographic locations hosted significantly different microbial symbiont communities, exhibiting a consistent relationship of lower symbiont similarity across

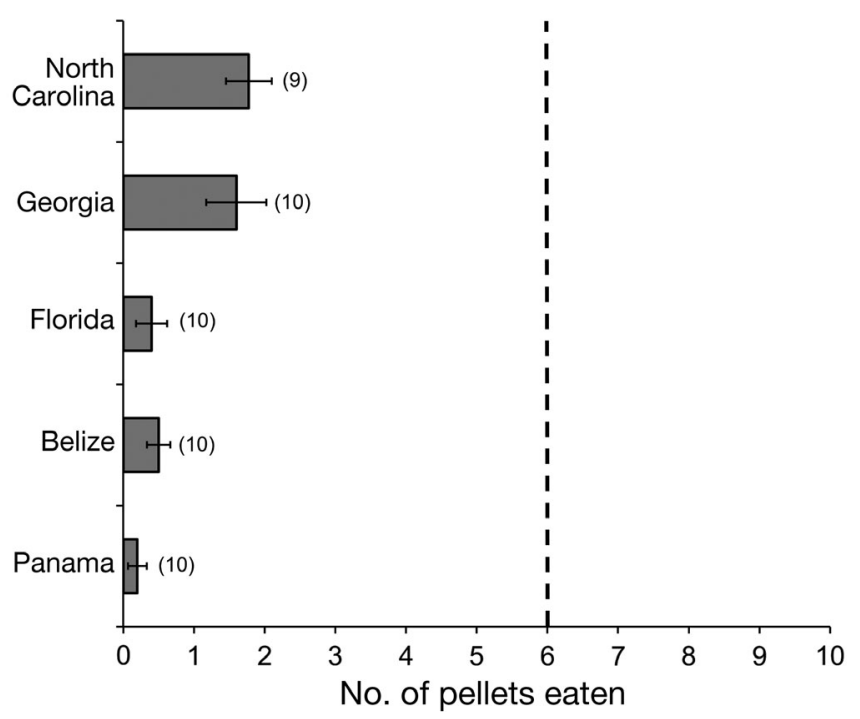

Fig. 4. Consumption by Thalassoma bifasciatum of pellets containing volumetric concentrations of crude organic extracts from Ircinia campana from different locations. Bars represent the mean number of pellets eaten $( \pm \mathrm{SD})$ with sample replication shown in parentheses. Extracts were considered deterrent if 6 or fewer pellets ( $\mathrm{p} \leq 0.057$, Fisher's exact test) were eaten (Marty \& Pawlik 2015), indicated by the dashed line greater geographic distance (i.e. distance-decay). Genetic characterization of host sponges delineated 2 haplotypes whose latitudinal distribution was consistent with variations in the microbiome. No variation in the chemical defense of $I$. campana was detected across the same latitudinal range, with crude extracts of all sponge samples unpalatable to the generalist predator Thalassoma bifasciatum. Together, these results revealed latitudinal variation in the microbiome of $I$. campana that correlated with host haplotype while having no effect on host antipredatory chemical defense.

Biogeographic patterns in the microbiomes of $I$. campana were characterized by more similar symbiont communities in temperate SAB regions compared to those from tropical Caribbean sites. Populations of I. campana from Florida hosted microbial communities less clearly differentiated from SAB and Caribbean samples, suggesting an influence of structuring factors both from northern and southern regions. The observed variations between microbial communities of I. campana were attributed to a complex consortium of symbiont taxa (OTUs). Consistent with previous studies of intraspecific variation in sponge symbionts (Luter et al. 2015, Weigel \& Erwin 2016), this consortium included dominant OTUs that were present in all hosts but at different relative abundances, as well as numerous, rare OTUs with regional exclusivity. Notably, most of the microbial taxa that contributed to microbial community variations were absent or extremely rare in free-living seawater communities, indicating that these differences were not strongly influenced by the composition of bacterioplankton in ambient seawater.

Latitudinal variation in sponge-associated microbial communities offers insight into the host-specific and environmental factors that structure hostsymbiont relationships. In free-living microbial communities, biogeographic patterns result from 2 key processes: dispersal limitation and environmental selection (Martiny et al. 2006). In host-associated microbial communities, dispersal is dictated by transmission mode: the passage of symbiont taxa via vertical (parent-to-offspring) or horizontal (environmental acquisition) means. Vertical symbiont transmission is documented in numerous sponges (Ereskovsky et al. 2005, Oren et al. 2005, Enticknap et al. 2006, de Caralt et al. 2007, Sharp et al. 2007, Lee et al. 2009, Schöttner et al. 2013), including the genus Ircinia (Schmitt et al. 2007), and links the evolutionary trajectory of host and symbiont. Accordingly, reproductive isolation of host populations may restrict 
the exchange of vertically transmitted microbes or genes that regulate the microbiome between host populations, resulting in divergent microbial communities over time (Schöttner et al. 2013, Easson \& Thacker 2014). The observed geographic distribution of host haplotypes for I. campana correlated with symbiont community similarity, suggesting that limited gene flow between SAB and Caribbean populations of I. campana may contribute to the observed latitudinal variation in symbiont communities. While larger sample sizes and higher resolution genetic markers are required to corroborate this hypothesis, even low levels of variation in COI sequences are informative, given the slow mutation rate of sponge mitochondrial genes (Huang et al. 2008, López-Legentil \& Pawlik 2009), and previous research reports a barrier to gene flow between $\mathrm{SAB}$ and Caribbean populations of other marine species (Carlin et al. 2003, Mobley et al. 2010, Betancur-R et al. 2011). Our results highlight the importance of host genetic characterization in discerning the effects of host-specific and environmental factors on microbiome variations across locations, as understanding the genetic structure and gene flow among host populations yields critical information about the dispersal range of symbionts via vertical transmission.

Environmental conditions vary greatly across the broad spatial scale in this study, from temperate SAB regions to tropical Caribbean reefs, and may exert different selective pressures on sponge holobionts that also contribute to the observed variability in microbiomes of I. campana. Although larval and adult sponge microbiomes are largely unresponsive to short-term, sub-lethal changes in environmental factors (e.g. temperature and nutrient loads; Webster et al. 2008, 2011, Simister et al. 2012a,b, Pita et al. 2013a), adaptations to local environmental conditions over longer timescales may drive region-specific differences in sponge microbiomes (Luter et al. 2015). Indeed, environmental variation is shown to impact symbiont communities from the same host sponge species, resulting in distinct symbiont communities between open-ocean sites and marine lakes (Cleary et al. 2013), intertidal and subtidal habitats (Weigel \& Erwin 2016), and inshore and offshore reefs (Luter et al. 2015). Similar environmental filtering of symbiont communities may contribute to the latitudinal variation detected in the microbial community of I. campana, with periodic environment-driven shifts in symbiont communities solidified by recurrent vertical symbiont transmission in isolated host populations, and may also explain the lack of variation in microbiomes of Ircinia species previously reported across more environmentally homogenous longitudinal gradients (Pita et al. 2013b,c).

Despite the observed latitudinal variation in symbiont communities, no variation in sponge tissue palatability was detected over the same geographic range using the fish-feeding laboratory assay. All populations of I. campana were chemically defended, suggesting that host palatability is decoupled from symbiont structure in I. campana. Similar findings are reported for the Caribbean congeneric sponge I. strobilina, where shifts in the bacterial symbionts under aquaculture conditions did not alter secondary metabolite profiles (Mohamed et al. 2008). The secondary metabolites responsible for feeding deterrence in I. campana were previously identified as a complex mixture of linear furanosesterterpene tetronic acids (Pawlik et al. 2002) and may be produced by shared components of the microbiome (i.e. core symbionts) or by metabolic pathways of the host sponge alone. While shifts in the specific composition of these complex mixtures may underlie the observed unpalatability, such hypothetical changes were not manifested in the ecological function investigated herein (i.e. predator deterrence). Additional ecological roles of secondary metabolites, such antifouling and allelopathic activity, were not investigated in the current study, and warrant investigation in future studies of structure-function relationships in the sponge microbiome.

Crude organic extracts of tissue samples of I. campana were consistently unpalatable across locations, with mean assay data ranging from 0 to 2 pellets of 10 eaten. Although mean values were higher at $\mathrm{SAB}$ locations, behavioral assay data should not be strictly interpreted to indicate quantitative differences in metabolite concentrations, as small differences in the mean number of pellets eaten more likely reflect variation in assay fish response due to hunger, time or date of assay, minor variations in extraction or assay food preparation among other factors (Pawlik 2012). Similar mean crude extract palatability values are also reported for samples of I. campana from Rodriguez Cay in the Florida Keys using the same extraction and assay techniques as the present study (Pawlik et al. 2002). The chemical defense data reported here contradict previous studies that suggest sponges from the SAB (including I. campana) are more palatable to fish predators than their conspecifics in the Caribbean (Ruzicka \& Gleason 2008, 2009). Importantly, these past studies do not directly compare the palatability of sponge tissue samples collected across a latitudinal gradient with side-byside feeding assays, but instead compare assay data 
for sponges from the SAB alone to assay data from Caribbean sponges published elsewhere and based on different extraction protocols. These methodological differences include lyophilization of tissue and the absence of an aqueous extraction phase (Ruzicka \& Gleason 2008, 2009) vs. fresh tissue with inclusion of an aqueous phase (Pawlik et al. 1995), and fieldbased feeding assays (mixed predators in situ; Ruzicka \& Gleason 2008, 2009) vs. laboratory feeding assays (single predator ex situ; Pawlik et al. 1995). The lower levels of chemical defenses observed in past studies of SAB sponges (Ruzicka \& Gleason $2008,2009)$ may be attributed to incomplete extraction of more polar secondary metabolites from sponge tissue during sample preparation (Pawlik 2012) and, to a lesser extent, bioassay conditions (given that extracts of Ircinia spp. exhibit predator deterrence in both single predator, laboratory assays, and mixed predator, field assays; Pawlik et al. 2002). In contrast, our study employed a standardized methodology (extraction protocols and assay conditions) performed on sponge tissue samples collected across a broad latitudinal gradient, and our results indicate that all tissue samples of I. campana were unpalatable to the generalist predator $T$. bifasciatum, regardless of collection site.

In conclusion, we report latitudinal variations and distance-decay relationships in the microbiome of $I$. campana across a $2500 \mathrm{~km}$ range extending from temperate $\mathrm{SAB}$ regions to tropical Caribbean reefs. Microbiome variations were driven by the different relative abundances of dominant, shared OTUs, as well as the presence/absence of rare, site-specific OTUs. No variation in palatability was detected over the same spatial scale, with chemical extracts from all samples of $I$. campana exhibiting predator deterrence using a standardized fish-feeding bioassay. Notably, distinct sponge haplotypes that correlated with the observed variability of symbiont community structure were detected. Together, these findings revealed latitudinal variation in the microbiome of $I$. campana and suggest that these biogeographic trends are driven by a combination of region-specific environmental filtering of symbiont communities and distinct evolutionary trajectories of host sponge populations.

Acknowledgements. We acknowledge field assistance and samples provided by Dr. Cole G. Easson (University of Alabama at Birmingham), Avery B. Paxton (University of North Carolina at Chapel Hill) and Sarah Fangman (Gray's Reef National Marine Sanctuary). Funding was provided by the National Science Foundation, Biological Oceanography Program (OCE-1029515, OCE-1558580).

\section{LITERATURE CITED}

Abdo Z, Schüette UME, Bent SJ, Williams CJ, Forney LJ, Joyce P (2006) Statistical methods for characterizing diversity of microbial communities by analysis of terminal restriction fragment length polymorphisms of $16 \mathrm{~S}$ rRNA genes. Environ Microbiol 8:929-938

Anderson MJ (2001) A new method for non-parametric multivariate analysis of variance. Austral Ecol 26:32-46

Anderson SA, Northcote PT, Page MJ (2010) Spatial and temporal variability of the bacterial community in different chemotypes of the New Zealand marine sponge Mycale hentscheli. FEMS Microbiol Ecol 72:328-342

Bates ST, Berg-Lyons D, Caporaso JG, Walters WA, Knight R, Fierer N (2011) Examining the global distribution of dominant archaeal populations in soil. ISME J 5:908-917

* Benjamini Y, Yekutieli D (2001) The control of the false discovery rate in multiple testing under dependency. Ann Stat 29:1165-1188

* Bennett GM, Moran NA (2015) Heritable symbiosis: the advantages and perils of an evolutionary rabbit hole. Proc Natl Acad Sci USA 112:10169-10176

Betancur-R R, Hines A, Acero PA, Ortí G, Wilbur AE, Freshwater DW (2011) Reconstructing the lionfish invasion: insights into Greater Caribbean biogeography. J Biogeogr 38:1281-1293

*Bewley CA, Faulkner DJ (1998) Lithistid sponges: star performers or hosts to the stars. Angew Chem Int Ed 37: 2162-2178

* Cárdenas CA, Bell JJ, Davy SK, Hoggard M, Taylor MW (2014) Influence of environmental variation on symbiotic bacterial communities of two temperate sponges. FEMS Microbiol Ecol 88:516-527

Carlin JL, Robertson DR, Bowen BW (2003) Ancient divergences and recent connections in two tropical Atlantic reef fishes Epinephelus adscensionis and Rypticus saponaceous (Percoidei: Serranidae). Mar Biol 143:1057-1069

Chanas B, Pawlik JR, Lindel T, Fenical W (1997) Chemical defense of the Caribbean sponge Agelas oroides (Schmidt). J Exp Mar Biol Ecol 208:185-196

Chao A (1984) Nonparametric estimation of the number of classes in a population. Scand J Stat 11:265-270

Chao A, Lee SM (1992) Estimating the number of classes via sample coverage. J Am Stat Assoc 87:210-217

C Clarke KR (1993) Non-parametric multivariate analyses of changes in community structure. Aust J Ecol 18:117-143

Clarke KR, Gorley RN (2006) PRIMER v6: user manual/tutorial. PRIMER-E, Plymouth

Cleary DFR, Becking LE, de Voogd NJ, Pires ACC, Polónia ARM, Egas C, Gomes NCM (2013) Habitat- and hostrelated variation in sponge bacterial symbiont communities in Indonesian waters. FEMS Microbiol Ecol 85: 465-482

Culman SW, Bukowski R, Gauch HG, Cadillo-Quiroz H, Buckley DH (2009) T-REX: software for the processing and analysis of T-RFLP data. BMC Bioinformatics 10:171

* Davy SK, Allemand D, Weis VM (2012) Cell biology of cnidarian-dinoflagellate symbiosis. Microbiol Mol Biol Rev 76:229-261

* de Caralt S, Uriz MJ, Wijffels RH (2007) Vertical transmission and successive location of symbiotic bacteria during embryo development and larva formation in Corticium candelabrum (Porifera: Demospongiae). J Mar Biol Assoc UK 87:1693-1699

* DeSantis TZ, Hugenholtz P, Larsen N, Rojas M and others 
(2006) Greengenes, a chimera-checked 16S rRNA gene database and workbench compatible with ARB. Appl Environ Microbiol 72:5069-5072

* Dray S, Dufour AB (2007) The ade4 package: implementing the duality diagram for ecologists. J Stat Softw 22:1-20

Easson CG, Thacker RW (2014) Phylogenetic signal in the community structure of host-specific microbiomes of tropical marine sponges. Front Microbiol 5:532

* Edgar RC, Haas BJ, Clemente JC, Quince C, Knight R (2011) UCHIME improves sensitivity and speed of chimera detection. Bioinformatics 27:2194-2200

KEnticknap JJ, Kelly M, Peraud O, Hill RT (2006) Characterization of a culturable alphaproteobacterial symbiont common to many marine sponges and evidence for vertical transmission via sponge larvae. Appl Environ Microbiol 72:3724-3732

Ereskovsky AV, Gonobobleva E, Vishnyakov A (2005) Morphological evidence for vertical transmission of symbiotic bacteria in the viviparous sponge Halisarca dujardini Johnston (Porifera, Demospongiae, Halisarcida). Mar Biol 146:869-875

* Erpenbeck D, Hooper JNA, Wörheide G (2006) CO1 phylogenies in diploblasts and the 'barcoding of life' - are we sequencing a suboptimal partition? Mol Ecol Notes 6: 550-553

Erwin PM, Thacker RW (2008) Phototrophic nutrition and symbiont diversity of two Caribbean sponge-cyanobacteria symbioses. Mar Ecol Prog Ser 362:139-147

Erwin PM, López-Legentil S, Schuhmann PW (2010) The pharmaceutical value of marine biodiversity for anticancer drug discovery. Ecol Econ 70:445-451

* Erwin PM, López-Legentil S, González-Pech R, Turon X (2012a) A specific mix of generalists: bacterial symbionts in Mediterranean Ircinia spp. FEMS Microbiol Ecol 79: 619-637

Erwin PM, Pita L, López-Legentil S, Turon X (2012b) Stability of sponge-associated bacteria over large seasonal shifts in temperature and irradiance. Appl Environ Microbiol 78:7358-7368

* Erwin PM, Coma R, López-Sendino P, Serrano E, Ribes M (2015) Stable symbionts across the HMA-LMA dichotomy: low seasonal and inter-annual variation in spongeassociated bacteria from taxonomically diverse hosts. FEMS Microbiol Ecol 91:fiv115

Esteves AIS, Hardoim CCP, Xavier JR, Gonçalves JMS, Costa R (2013) Molecular richness and biotechnological potential of bacteria cultured from Irciniidae sponges in the north-east Atlantic. FEMS Microbiol Ecol 85:519-536

Felsenstein J (1985) Confidence limits on phylogenies: an approach using the bootstrap. Evolution 39:783-791

FFórez LV, Biedermann PHW, Engl T, Kaltenpoth M (2015) Defensive symbioses of animals with prokaryotic and eukaryotic microorganisms. Nat Prod Rep 32:904-936

Folmer O, Black M, Hoeh W, Lutz R, Vrijenhoek R (1994) DNA primers for amplification of mitochondrial cytochrome c oxidase subunit I from diverse metazoan invertebrates. Mol Mar Biol Biotechnol 3:294-299

Freeman CJ, Thacker RW (2011) Complex interactions between marine sponges and their symbiotic microbial communities. Limnol Oceanogr 56:1577-1586

Freeman CJ, Thacker RW, Baker DM, Fogel ML (2013) Quality or quantity: is nutrient transfer driven more by symbiont identity and productivity than by symbiont abundance? ISME J 7:1116-1125

F Freeman MF, Vagstad AL, Piel J (2016) Polytheonamide biosynthesis showcasing the metabolic potential of sponge-associated uncultivated 'Entotheonella' bacteria. Curr Opin Chem Biol 31:8-14

*Gaiero JR, McCall CA, Thompson KA, Day NJ, Best AS, Dunfield KE (2013) Inside the root microbiome: bacterial root endophytes and plant growth promotion. Am J Bot 100:1738-1750

Hardoim CCP, Costa R (2014) Temporal dynamics of prokaryotic communities in the marine sponge Sarcotragus spinosulus. Mol Ecol 23:3097-3112

*Hasegawa M, Kishino H, Yano T (1985) Dating of the human-ape splitting by a molecular clock of mitochondrial DNA. J Mol Evol 22:160-174

*Hebert PDN, Cywinska A, Ball SL, DeWaard JR (2003) Biological identifications through DNA barcodes. Proc R Soc B 270:313-321

*Hentschel U, Usher KM, Taylor MW (2006) Marine sponges as microbial fermenters. FEMS Microbiol Ecol 55:167-177

* Hentschel U, Piel J, Degnan SM, Taylor MW (2012) Genomic insights into the marine sponge microbiome. Nat Rev Microbiol 10:641-654

* Hongoh Y (2011) Toward the functional analysis of uncultivable, symbiotic microorganisms in the termite gut. Cell Mol Life Sci 68:1311-1325

* Huang D, Meier R, Todd PA, Chou LM (2008) Slow mitochondrial COI sequence evolution at the base of the metazoan tree and its implications for DNA barcoding. J Mol Evol 66:167-174

Huse SM, Welch DM, Morrison HG, Sogin ML (2010) Ironing out the wrinkles in the rare biosphere through improved OTU clustering. Environ Microbiol 12:1889-1898

* Kearse M, Moir R, Wilson A, Stones-Havas S and others (2012) Geneious Basic: an integrated and extendable desktop software platform for the organization and analysis of sequence data. Bioinformatics 28:1647-1649

Larkin MA, Blackshields G, Brown NP, Chenna R and others (2007) Clustal W and Clustal X version 2.0. Bioinformatics 23:2947-2948

ㄴLee OO, Chui PY, Wong YH, Pawlik JR, Qian PY (2009) Evidence for vertical transmission of bacterial symbionts from adult to embryo in the Caribbean sponge Svenzea zeai. Appl Environ Microbiol 75:6147-6156

*LLee OO, Wang Y, Yang J, Lafi FF, Al-Suwailem A, Qian PY (2011) Pyrosequencing reveals highly diverse and species-specific microbial communities in sponges from the Red Sea. ISME J 5:650-664

KLeong W, Pawlik JR (2010) Evidence of a resource trade-off between growth and chemical defenses among Caribbean coral reef sponges. Mar Ecol Prog Ser 406:71-78

*Loh TL, Pawlik JR (2014) Chemical defenses and resource trade-offs structure sponge communities on Caribbean coral reefs. Proc Natl Acad Sci USA 111:4151-4156

* López-Legentil S, Pawlik JR (2009) Genetic structure of the Caribbean giant barrel sponge Xestospongia muta using the I3-M11 partition of COI. Coral Reefs 28:157-165

* Luter HM, Widder S, Botté ES, Wahab MA and others (2015) Biogeographic variation in the microbiome of the ecologically important sponge, Carteriospongia foliascens. PeerJ 3:e1435

* Martínez-Murcia AJ, Acinas SG, Rodriguez-Valera F (1995) Evaluation of prokaryotic diversity by restrictase digestion of $16 \mathrm{~S}$ rDNA directly amplified from hypersaline environments. FEMS Microbiol Ecol 17:247-255

* Martiny JBH, Bohannan BJM, Brown JH, Colwell RK and others (2006) Microbial biogeography: putting micro- 
organisms on the map. Nat Rev Microbiol 4:102-112

Marty MJ, Pawlik JR (2015) A fish-feeding laboratory bioassay to assess the antipredatory activity of secondary metabolites from the tissues of marine organisms. J Vis Exp 95:52429

McArdle BH, Anderson MJ (2001) Fitting multivariate models to community data: a comment on distance-bases redundancy analysis. Ecology 82:290-297

McFall-Ngai M (2008) Host-microbe symbiosis: the squidVibrio association-a naturally occurring, experimental model of animal/bacterial partnerships. Adv Exp Med Biol 635:102-112

McFall-Ngai M, Hadfield MG, Bosch TCG, Carey HV and others (2013) Animals in a bacterial world, a new imperative for the life sciences. Proc Natl Acad Sci USA 110: 3229-3236

Meyer CP, Geller JB, Paulay G (2005) Fine scale endemism on coral reefs: archipelagic differentiation in turbinid gastropods. Evolution 59:113-125

Mobley KB, Small CM, Jue NK, Jones AG (2010) Population structure of the dusky pipefish (Syngnathus floridae) from the Atlantic and Gulf of Mexico, as revealed by mitochondrial DNA and microsatellite analyses. J Biogeogr 37:1363-1377

Mohamed NM, Rao V, Hamann MT, Kelly M, Hill RT (2008) Monitoring bacterial diversity of the marine sponge Ircinia strobilina upon transfer into aquaculture. Appl Environ Microbiol 74:4133-4143

Moran NA (2007) Symbiosis as an adaptive process and source of phenotypic complexity. Proc Natl Acad Sci USA 104:8627-8633

* Olson JB, Gao X (2013) Characterizing the bacterial associates of three Caribbean sponges along a gradient from shallow to mesophotic depths. FEMS Microbiol Ecol 85: 74-84

Oren M, Steindler L, Ilan M (2005) Transmission, plasticity and the molecular identification of cyanobacterial symbionts in the Red Sea sponge Diacarnus erythraenus. Mar Biol 148:35-41

Pawlik JR (2011) The chemical ecology of sponges on Caribbean reefs: natural products shape natural systems. Bioscience 61:888-898

Pawlik JR (2012) Antipredatory defensive roles of natural products from marine invertebrates. In: Fattorusso E, Gerwick WH, Taglialatela-Scafati O (eds) Handbook of marine natural products. Springer, Dordrecht, p 677-710

Pawlik JR, Chanas B, Toonen R, Fenical W (1995) Defenses of Caribbean sponges against predatory reef fish. I. Chemical deterrency. Mar Ecol Prog Ser 127:183-194

Pawlik JR, McFall G, Zea S (2002) Does the odor from sponges of the genus Ircinia protect them from fish predators? J Chem Ecol 28:1103-1115

Piel J (2009) Metabolites from symbiotic bacteria. Nat Prod Rep 26:338-362

Pita L, Erwin PM, Turon X, López-Legentil S (2013a) Till death do us part: stable sponge-bacteria associations under thermal and food shortage stresses. PLOS ONE 8: e80307

Pita L, López-Legentil S, Erwin P (2013b) Biogeography and host fidelity of bacterial communities in Ircinia spp. from the Bahamas. Microb Ecol 66:437-447

Pita L, Turon X, López-Legentil S, Erwin PM (2013c) Host rules: spatial stability of bacterial communities associated with marine sponges (Ircinia spp.) in the western Mediterranean Sea. FEMS Microbiol Ecol 86:268-276
R Core Team (2014) R: a language and environment for statistical computing. R Foundation for Statistical Computing, Vienna

Keveillaud J, Maignien L, Eren AM, Huber JA, Apprill A, Sogin ML, Vanreusel A (2014) Host-specificity among abundant and rare taxa in the sponge microbiome. ISME J 8:1198-1209

Kobles Alonso V, Guarner F (2013) Linking the gut microbiota to human health. Br J Nutr 109:S21-S26

Rot C, Goldfarb I, Ilan M, Huchon D (2006) Putative crosskingdom horizontal gene transfer in sponge (Porifera) mitochondria. BMC Evol Biol 6:71

Ruzicka R, Gleason DF (2008) Latitudinal variation in spongivorous fishes and the effectiveness of sponge chemical defenses. Oecologia 154:785-794

Kuzicka R, Gleason DF (2009) Sponge community structure and anti-predator defenses on temperate reefs of the South Atlantic Bight. J Exp Mar Biol Ecol 380:36-46

Schloss PD, Westcott SL, Ryabin T, Hall JR and others (2009) Introducing mothur: open-source, platform-independent, community-supported software for describing and comparing microbial communities. Appl Environ Microbiol 75:7537-7541

Schmitt S, Weisz JB, Lindquist N, Hentschel U (2007) Vertical transmission of a phylogenetically complex microbial consortium in the viviparous sponge Ircinia felix. Appl Environ Microbiol 73:2067-2078

Schmitt S, Tsai P, Bell J, Fromont J and others (2012) Assessing the complex sponge microbiota: core, variable and species-specific bacterial communities in marine sponges. ISME J 6:564-576

* Schöttner S, Hoffmann F, Cárdenas P, Rapp HT, Boetius A, Ramette A (2013) Relationships between host phylogeny, host type and bacterial community diversity in coldwater coral reef sponges. PLOS ONE 8:e55505

Shannon CE (1948) A mathematical theory of communication. Bell Syst Tech J 27:379-423

Sharp KH, Eam B, Faulkner DJ, Haygood MG (2007) Vertical transmission of diverse microbes in the tropical sponge Corticium sp. Appl Environ Microbiol 73:622-629

Shigenobu S, Wilson ACC (2011) Genomic revelations of a mutualism: the pea aphid and its obligate bacterial symbiont. Cell Mol Life Sci 68:1297-1309

Simister R, Taylor MW, Tsai P, Fan L, Bruxner TJ, Crowe ML, Webster N (2012a) Thermal stress responses in the bacterial biosphere of the Great Barrier Reef sponge, Rhopaloeides odorabile. Environ Microbiol 14:32323246

Simister R, Taylor MW, Tsai P, Webster N (2012b) Spongemicrobe associations survive high nutrients and temperatures. PLOS ONE 7:e52220

Simister R, Taylor MW, Rogers KM, Schupp PJ, Deines P (2013) Temporal molecular and isotopic analysis of active bacterial communities in two New Zealand sponges. FEMS Microbiol Ecol 85:195-205

Simpson EH (1949) Measurement of diversity. Nature 163: 688

* Smith SE, Smith FA (2011) Roles of arbuscular mycorrhizas in plant nutrition and growth: new paradigms from cellular to ecosystem scales. Annu Rev Plant Biol 62:227-250

* Tamura K, Stecher G, Peterson D, Filipski A, Kumar S (2013) MEGA6: molecular evolutionary genetics analysis version 6.0. Mol Biol Evol 30:2725-2729

Taylor MW, Schupp PJ, de Nys R, Kjelleberg S, Steinberg PD (2005) Biogeography of bacteria associated with the 
marine sponge Cymbastela concentrica. Environ Microbiol 7:419-433

Taylor MW, Radax R, Steger D, Wagner M (2007) Spongeassociated microorganisms: evolution, ecology, and biotechnological potential. Microbiol Mol Biol Rev 71: 295-347

Thacker RW, Freeman CJ (2012) Sponge-microbiome symbioses: recent advances and new directions. Adv Mar Biol 62:57-111

Thiel V, Leininger S, Schmaljohann R, Brümmer F, Imhoff JF (2007) Sponge-specific bacterial associations of the Mediterranean sponge Chondrilla nucula (Demospongiae, Tetractinomorpha). Microb Ecol 54:101-111

Thomas T, Moitinho-Silva L, Lurgi M, Björk JR and others (2016) Diversity, structure and convergent evolution of the global sponge microbiome. Nat Commun 7:11870

Turner S, Pryer KM, Miao VPW, Palmer JD (1999) Investigating deep phylogenetic relationships among cyanobacteria and plastids by small subunit rRNA sequence analysis. J Eukaryot Microbiol 46:327-338

Editorial responsibility: Pei-Yuan Qian, Kowloon, Hong Kong SAR
Webster NS, Taylor MW (2012) Marine sponges and their microbial symbionts: love and other relationships. Environ Microbiol 14:335-346

Webster NS, Cobb RE, Negri AP (2008) Temperature thresholds for bacterial symbiosis with a sponge. ISME J 2: 830-842

* Webster NS, Botté ES, Soo RM, Whalan S (2011) The larval sponge holobiont exhibits high thermal tolerance. Environ Microbiol Rep 3:756-762

* Webster NS, Luter HM, Soo RM, Botté ES, Simister RL, Abdo D, Whalan S (2013) Same, same but different: symbiotic bacterial associations in GBR sponges. Front Microbiol 3: 444

Weigel BL, Erwin PM (2016) Intraspecific variation in microbial symbiont communities of the sun sponge, Hymeniacidon heliophila, from intertidal and subtidal habitats. Appl Environ Microbiol 82:650-658

* Yilmaz P, Parfrey LW, Yarza P, Gerken J and others (2014) The SILVA and 'All-species Living Tree Project (LTP)' taxonomic frameworks. Nucleic Acids Res 42:D643-D648

Submitted: July 1, 2016; Accepted: December 13, 2016 Proofs received from author(s): February 9, 2017 